\title{
УДК 331.44:371.1
}

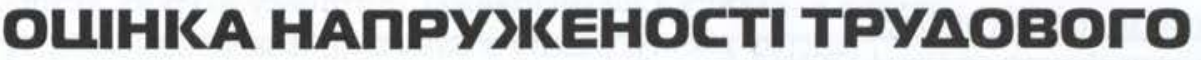 ПРОUЕСУ ВЧИТЕАЯ ЗАГААЬНООСВITНЬОГО

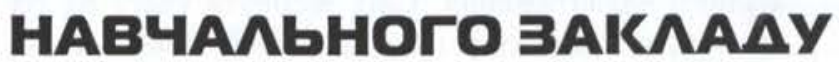

\section{ヘатіна Г.O.}

\section{Сумський Аержавний пеАагогічний університет ім. А.С.Макаренка}

Відсутність нормативного статусу педагогічної діяльності та оцінки напруженості трудового процесу згідно 3 Гігієнічною класифікацією праці визначають актуальність проблеми. На підставі аналізу фактичного робочого навантаження вчителів за даними хронометражу вивчено розподіл робочого часу на виконання службових обов'язків. Встановлено порушення режиму праці вчителя за рахунок збільшення тижневого навантаження. Згідно $з$ критеріями Гігієнічної класифікації праці напруженість трудового процесу вчителя віднесена до III класу 3 ступеня.

Ключові слова: вчитель, напруженість праці, хронометраж

\section{Вступ}

Національна доктрина визначає прискорений випереджальний інноваційний розвиток освіти в першій чверті XXI століття, що потребує розробки нових теоретико-методологічних засад для системного осмислення діяльності педагога [1].

На Україні спостерігається відсутність оновлення педагогічних кадрів - лише $30,5 \%$ студентів починають працювати за фахом. У зв'язку з цим підвищується кадрова мобільність, знижується трудова активність та рівень здоров'я педагогічних кадрів [1]. Також визначальною проблемою сучасної освіти є розвиток емоційного вигорання сучасного вчителя, першочерговою причиною якого є організаційні фактори: багатогодинна ненормована праця, невизначеність обов'язків з боку адміністрації $[2,3]$. Психологи зазначають, що близько $80 \%$ вчителів мають емоційне напруження [4]. Крім того, творчий характер професії, вимагає від вчителя максимальної самовіддачі без гарантії щодо відповідної винагороди його праці [5]. Така ситуація призводить до зниження стану здоров'я вчителів і вимагає, в умовах суспільної трансформації і реформ освіти, проведення наукових досліджень з гігієнічної оцінки умов праці вчителя. Актуальною є проблема розробки нормативного статусу педагогічної діяльності, який передбачає врахування витрат часу на усі ї̈ елементи та $€$ критерієм специфічності професії за рядом ознак (інтелектуальні, сенсорні, емоційні навантаження та режиму праці).

Аналіз останніх досліджень і публікацій. На сьогодні в Україні нараховується близько 586,6 тис. вчителів, які навчають понад 61 млн учнів у 21 ти- сячі загальноосвітніх шкіл [5]. Основною метою праці вчителя $€$ навчання та виховання підростаючого покоління на високому розумовому та фізичному рівні [6]. Професія вчителя належить до розумового виду праці у складній системі психосоціальних відносин «людина-людина» [7]. Дані соціологічних та хронометражних досліджень 70-х років XX століття свідчать про високу напруженість праці вчителя через ненормованість позаурочної роботи, яка складається з: підготовки до уроку, перевірки зошитів, складання звітів, виховної роботи 3 дітьми та спілкування з батьками. Хронометражні спостереження свідчать про 10-11-годинне навантаження вчителя протягом доби, що за тиждень складає близько 28-32 год перепрацювання через підготовку наочності, складання звітів та довідок [6-9]. Окрім того, існують дані про додаткову роботу вдома у вечірній час, що призводить до інтелектуального та психоемоційного напруження, особливо у жіночого контингенту, який становить 80-90\% викладацького складу шкіл [10].

Нині не існує узагальненої характеристики розподілу добового часу вчителя з урахуванням специфіки праці та позаурочного навантаження. Аналіз попередніх наукових досліджень свідчить про перевагу соціологічних та хронометражних методів досліджень умов праці і відсутність оцінки напруженості праці вчителя згідно з критеріями Гігієнічної класифікації праці.

Мета роботи: оцінити ступінь напруженості трудового процесу вчителя загальноосвітнього навчального закладу. Провести хронометражні дослідження та розробити узагальнену характеристику розподілу добового часу вчителя. 


\section{Матеріали та методи дослідження}

Оцінка напруженості трудового процесу проведена за 12 основними показниками відповідно Гігієнічної класифікації праці ГН 3.3.5-3.3.8;6.6.1 -083$2001[11]$.

Кінцева оцінка напруженості праці встановлювалась за показником, який має найвищий ступінь напруженості. У тих випадках, коли більше 6-ти показників мали оцінку III.I та III.2, напруженість трудового процесу оцінювалася на один ступінь вище, тобто третій клас другого ступеня, або третій клас третього ступеня.

Проведено 70 хронометражних спостережень робочого часу вчителів старших класів віком від $31-60$ років зі стажем від 5 до 33 років в умовах двох загальноосвітніх навчальних закладів. При спостереженні враховували загальні рекомендації щодо методики проведення хронометражу праці [12]. Використано методи аналізу та елементарного структурування робочого часу, поелементний хронометраж витрат часу вчителя на виконання всіх елементів професійної діяльності. Проведено опитування 84 вчителів за розробленою нами анкетою (табл. 1). Суб'єктивну оцінку функціонального стану організму визначали за допомогою психологічного тесту САН [13].

\section{Результати досліджень та їх обговорення}

Хронометражне спостереження дозволило встановити, що зміст, структура і характер праці вчителя мають певні особливості. Середнє значення тижневого навантаження становить $21,9 \pm 0,8$ год, що на 4 год перевищує встановлену норму 18-годинного робочого тижня [14]. Визначене навантаження мають $85 \%$ вчителів. Це призводить до того, що у більшості вчителів залишається лише 1 вихідний день. Питома вага вчителів з двома вихідними днями становить $29,8 \%$. Окрім того, під час учбового процесу (уроків) вчитель не завжди має час на відпочинок і вживання їжі. Перерви між уроками $є$ робочим часом вчителя.

Аналіз професійної діяльності вчителя дозволив визначити такі структурні елементи професійної діяльності: підготовчі, основні та допоміжні. Підготовчі елементи (підготовка до уроку, пошук журналу, перегляд об'яв адміністрації закладу, пошук у розкладі класу) складають від 5,4 хв до 27,5 хв робочого дня. Основним елементом роботи вчителя є проведення уроків - від 5,6 год по понеділках до 3,6 год по суботах, що свідчить про нерівномірність навантаження. Витрати часу на перевірку зошитів, роботу з документацією, підготовку до уроку, виховну роботу, роботу з батьками, класне керівництво, відвідування педагогічних рад становлять до 5,24 год денного навантаження. Слід звернути увагу на те, що творчий характер праці вчителя сприяє збільшенню витрат часу на ті структурні елементи роботи, що не піддаються чіткому хронометражу. Наприклад, це пов'язано з необхідністю підготовки до уроків вдома. Така підготовка займає від 1 до 6 год на день. Підрахунок часу на написання звітів, перевірку умов життя дітей мікрорайону, підготовку наочних приладь, ведення стендів обмежується у зв'язку з відсутністю чіткого графіку ї проведення.

Таким чином, дані дослідження свідчать про велику фактичну тривалість робочого часу вчителя, що становить від 9,3 до 11,11 год. При цьому встановлено, що витрати часу вчителя на сон становлять від $7,4 \pm 0,18$ год по буднях до $8,2 \pm 0,18$ год у вихідні. У середньому на догляд за власними дітьми вчитель витрачає до $0,7 \pm 0,2$ год. Пасивний відпочинок переважає над активним: перегляд телепередач $-1,6 \pm 0,13$ год, читання $-1,1 \pm 0,1$ год, заняття спортом, зокрема ранковою гігієнічною гімнастикою - $0,1 \pm 0,3$ год, прогулянки пішки, за рахунок дороги з роботи $-0,2 \pm 0,03$ год. На свіжому повітрі у робочі дні вчитель перебуває не більше 30 хв. Такий розподіл добового часу свідчить про перевагу ненормованої праці, гіподинамії вчителів загальноосвітніх навчальних закладів, що підтверджуеться попередніми дослідженнями науковців [6-9]. Так, за даними хронометражних спостережень Л.І.Томашевської, загальна тривалість робочоro часу вчителів складала 9-10 год, а $85 \%$ опитаних осіб мали низьку фізичну активність [9].

Оцінку напруженості трудового процесу вчителя проведено за показниками, що характеризують інтелектуальні, сенсорні, емоційні навантаження та режим праці. Оцінку інтелектуального навантаження вчителя здійснювали з урахуванням вимог до психолого-педагогічної підготовки вчителя. Педагогічна діяльність визначаеться, як творча робота без наявного алгоритму дій [15]. Основними інформаційними сигналами, що надходять до вчителя під час роботи, вважали сигнали основного елементу праці уроку. Інформацією для вчителя $є$ зміст відповіді дітей на уроці в усній чи письмовій формі. Вчитель зобов'язаний сприйняти відповідь, порівняти 3 поданим раніше матеріалом, тобто номінальним значенням інформації, що надходить, та надати заключну оцінку фактичної, тобто поданої учнем, інформації. 
Зразок анкети

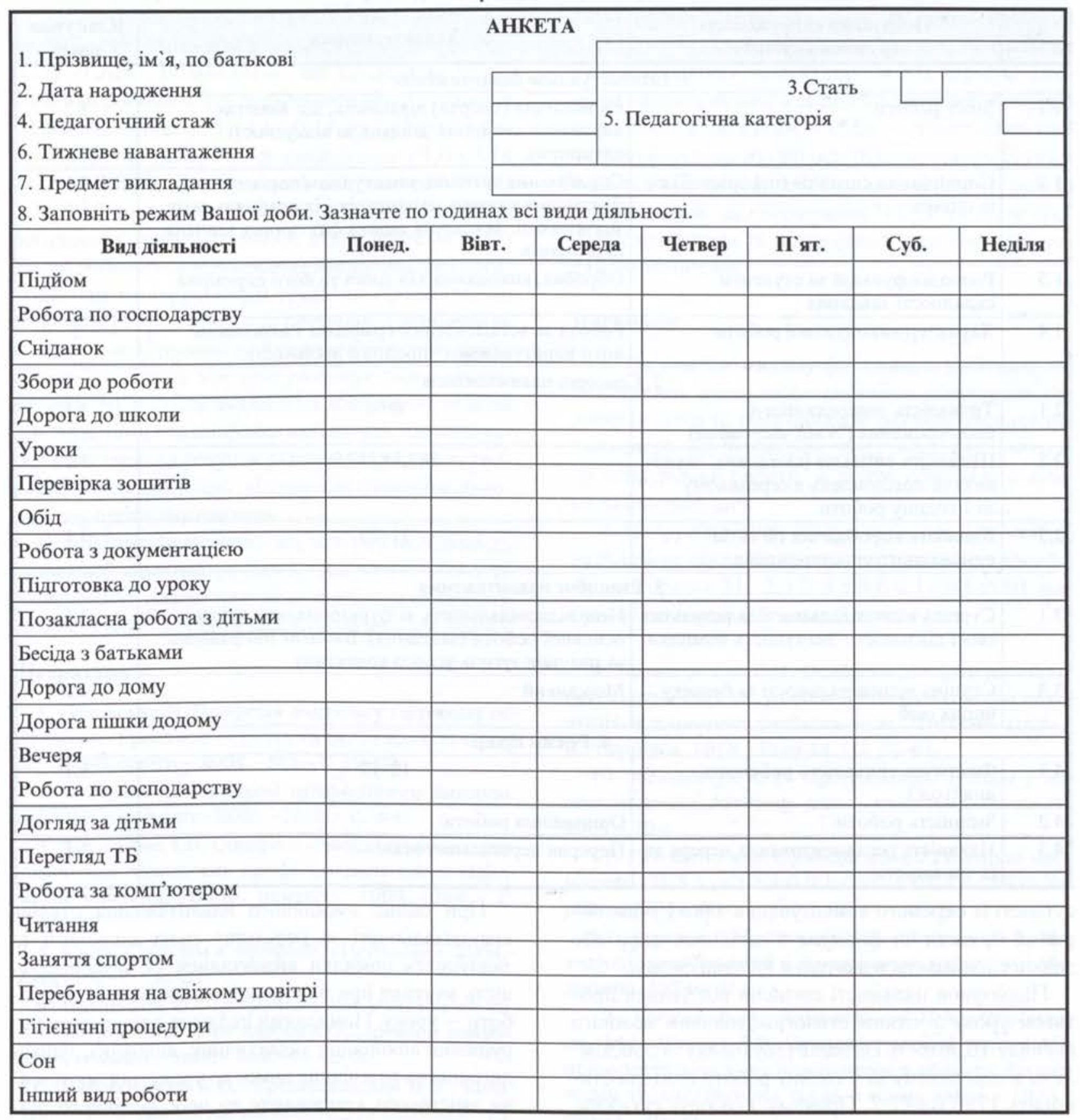

Також до основного компоненту уроку належить не тільки сприйняття вчителем усної інформації, а й контроль за виконанням учнями інших, в тому числі письмових завдань. Виконання роботи вчителем відбувається за розкладом уроків школи, який може підлягати коригуванню у ході діяльності: відміна або вставлення додаткових уроків тощо (табл. 2).

Звертаючи увагу на визначення сенсорних навантажень, слід зазначити, що при вивченні щільності сигналів (звукових) та повідомлень у середньому за 1 годину роботи сигналом для вчителя $є$ окремо почуте слово при відповіді учня (учнів), співробітників, дирекції. Також до інформації, що складає щільність сигналів, належить інформація, отримана вчителем при перевірці зошитів. У вчителів математики, фізики та хімії характер самих інформаційних сигналів дещо інший, ніж у викладачів гуманітарних предметів. Під час вирішення учнем задач, при від- 
Показники напруженості трудового процесу вчителя

\begin{tabular}{|c|c|c|c|}
\hline № & $\begin{array}{l}\text { Показники напруженості } \\
\text { трудового процесу }\end{array}$ & Характеристика & $\begin{array}{l}\text { Клас умов } \\
\text { праці }\end{array}$ \\
\hline \multicolumn{4}{|c|}{ 1. Інтелектуальне навантаження } \\
\hline 1.1 & Зміст роботи & $\begin{array}{l}\text { Евристична (творча) діяльність, що вимагає } \\
\text { вирішення складних завдань за відсутності } \\
\text { алгоритму }\end{array}$ & 3.2 \\
\hline 1.2 & $\begin{array}{l}\text { Сприймання сигналів (інформаціі) та } \\
\text { ї оцінка }\end{array}$ & $\begin{array}{l}\text { Сприймання сигналів } 3 \text { наступним порівнянням } \\
\text { фактичних значень параметрів } 3 \text { ї номінальними } \\
\text { значеннями. Заключна оцінка фактичних значень } \\
\text { параметрів }\end{array}$ & 3.1 \\
\hline 1.3 & $\begin{array}{l}\text { Розподіл функцій за ступенем } \\
\text { складності завдання }\end{array}$ & Обробка, виконання завдання та його перевірка & 2 \\
\hline 1.4 & Характер виконуваної роботи & $\begin{array}{l}\text { Робота за встановленим графіком з можливим } \\
\text { його коригуванням упродовж діяльності }\end{array}$ & 2 \\
\hline \multicolumn{4}{|c|}{ 2. Сенсорні навантаження } \\
\hline 2.1 & $\begin{array}{l}\text { Тривалість зосередженого } \\
\text { спостереження (\% від часу зміни) }\end{array}$ & $66 \%$ & 3.1 \\
\hline 2.2 & $\begin{array}{l}\text { Щільність ситналів (світлових, звуко- } \\
\text { вих) та повідомлень в середньому } \\
\text { за } 1 \text { годину роботи }\end{array}$ & $382,8 \pm 217,9$ & 3.2 \\
\hline 2.3 & $\begin{array}{l}\text { Кількість виробничих об'єктів } \\
\text { одночасного спостереження }\end{array}$ & $11-25$ & 3.1 \\
\hline \multicolumn{4}{|c|}{ 3. Емоційне навантаження } \\
\hline 3.1 & $\begin{array}{l}\text { Ступінь відповідальності за результат } \\
\text { своєі діяльності. Значущість помилки }\end{array}$ & $\begin{array}{l}\text { Несе відповідальність за функціональну якість } \\
\text { основної роботи (завдання). Вимагає виправлень } \\
\text { за рахунок зусиль усього колективу } \\
\end{array}$ & 3.1 \\
\hline 3.3. & $\begin{array}{l}\text { Ступінь відповідальності за безпеку } \\
\text { інших осіб }\end{array}$ & Можливий & 3.2 \\
\hline \multicolumn{4}{|c|}{ 4. Режим праці } \\
\hline 4.1 & $\begin{array}{l}\text { Фактична тривалість робочого } \\
\text { дня (год.) }\end{array}$ & $10-12$ & 3.1 \\
\hline 4.2 & Змінність роботи & Однозмінна робота & 1 \\
\hline 4.3 & $\begin{array}{l}\text { Наявність регламентованих перерв та } \\
\text { їх тривалість }\end{array}$ & Перерви нерегламентовані & 3.1 \\
\hline
\end{tabular}

сутності їх окремого коментування з боку учня, окремий приклад чи формула 3 декількох цифр або знаків сприймається вчителем як один сигнал.

Підрахунок щільності сигналів відбувався протягом уроку з чітким стенографуванням кожного сигналу. Щільність сигналів (звукових) та повідомлень в середньому за 1 годину роботи вчителя становить $1726,6 \pm 77,7$. Причому, кількість сигналів, поданих вчителем $(1051,8 \pm 65,6 /$ год) переважає кількість сигналів, сприйнятих від учнів $(382,8 \pm$ 217,9 /год), що підтверджується фіксацією часу, протягом якого вчитель говорить $-21,5 \pm 1,8$ хв/год. Як видно з таблиці 2, характеристикою щільності сигналів, що сприймає вчитель, є інформація, отримана при відповіді учнів. Матеріал, який викладає вчитель, слід відносити до евристичної діяльності.
При оцінці емоційного навантаження ступінь відповідальності за результат своєї діяльності та значущість помилки визначалися як відповідальність вчителя при виконання основної частини роботи - уроку. Помилками педагога вважається порушення виконання дидактичних, виховних, психологічних та гігієнічних вимог до уроку: від порушення змістового компоненту до необ'єктивного оцінювання знань, психологічного та морального тиску на учня. При цьому ступінь відповідальності вчителя за безпеку учнів у межах навчального закладу дуже високий, за класифікацією встановлений як можливий (див. табл. 2).

Таким чином, напруженість праці вчителя за найвищим показником має бути віднесена до III.2. Але з урахуванням того, що більше 6 показників мають оцінку III.1 та III.2, напруженість трудового 
процесу вчителя слід оцінити на ступінь вище, тобто III клас 3 ступінь.

Дослідження функціонального стану вчителів у динаміці трудового дня проводилося за допомогою тесту «САН». Встановлено, що від початку до закінчення робочого дня відбувалося різке зниження показника активності $34,6 \pm 0,11$ до $3,55 \pm 0,11$ ба-

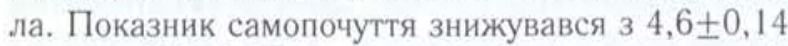
бала до $3,6 \pm 0,13$, тобто на 1 бал, настрою - від $5,1 \pm 0,12$ до $4,1 \pm 0,12$ бала $(p<0,001)$. Вірогідно погіршення функціонального стану вчителів в динаміці робочого дня зумовлене нераціонально організованим та напруженим трудовим процесом, що за даними [13] свідчить про поступове накопичення ознак втоми. Отримані дані результатів оцінки функціонального стану вчителів узгоджуються з дослідженням [8], в якому вказано на збільшення різниці між середніми показниками активності, самопочуття та настрою за рахунок різкого зниження активності, що свідчить про погіршення функціонального стану організму вчителя.

Результати досліджень свідчать про необхідність подальшої наукової регламентації навчального та позаурочного навантаження вчителів з урахуванням предмету викладання та класу напруженості праці.

\section{Література}

1. Пуховська Л. Професія вчителя у світовому освітньому просторі: статистичні характеристики//Шлях освіти.-2004.- №1.- С.17-20.

2. Федієнко О. Синдром професійного вигорання//Шкільний світ.- 2005.- №39.- С. 4-6.

3. Форманюк Т.В. Синдром «Эмоционального сгорания" как показатель профессиональной дезадаптации учителя//Вопр. психол.- 1994.- №6.- С. 57-64.

4. Сапа I. Полум'я професіі//Психолог:- 2004.№20(116).- C. 30-31.

5. Виговська О. Професіоналізм учителя як гарант збереження його здоров'я//Директор школи, ліцею, гімназії.- 2005.- №2.- С. 48-50.

6. Навакатикян А.О., Крыжановская В.В., Кальныш В.В. Физиология и гигиена умственного труда.-К.: Здоров'я, 1987.- 150 с.

7. Карпенко А.В. Выделение катехоламинов, кортикостероидов с мочой и структура сердечного ритма при умственном труде различной напряженности (у преподавателей средней школы): Автореф. дис. ... канд. мед. наук.- К., 1976.- 31 с.

8. Доронкина Е.К. Некоторые психофизиологические особенности труда учителей//Физиол. человека.- 1976.- Т.2, №5.- С. 825-828.
Також, в умовах навчальних закладів, необхідно впровадження виробничої гімнастики з елементами автогенного тренування. Так, за рекомендаціями А.О.Навакатикяна, створення гарного психологічного мікроклімату колективу знизить нервово-емоційне навантаження, а активний відпочинок поряд 3 повноцінним пасивним - сном - сприятимуть підвищенню рухової активності [6]. Виробнича гімнастика під час уроків, зокрема динамічні перерви та фізкультпаузи, за свідченнями [16], є засобом профілактики втоми та підвищення загальної працездатності вчителів.

\section{Висновки}

1. На підставі аналізу фактичного робочого навантаження вчителів встановлено порушення режиму ї праці та відпочинку за рахунок збільшення тижневого навантаження, відсутності регламентації позаурочної роботи, а також обмеження кількості вихідних днів.

2. Напруженість праці вчителя загальноосвітніх навчальних закладів згідно 3 «Гігієнічною класифікацією праці» ГН 3.3.5-3.3.8;6.6.1-083-2001 має бути віднесено до III класу 3 ступеня.

9. Томашевская Л.И. Особенности функционального состояния ССС учителей при накоплении утомления в динамике учебного года//Гигиена труда.К.: Здоров'я, 1978.- Вып. 14.- С. 52-61.

10. Мельничук Ю.Б. Програмовані пологи у жінок-педагогів: Автореф. дис. ... канд. мед. наук.- К., 2001.- 19 c.

11. Гігієнічна класифікація праці: Гігієнічні нормативи ГН 3.3.5-3.3.8;6.6.1-083-2001.- К.: МОЗ УКраїни, 2001.- 46 c.

12. Горшков С.И., Золина З.М., Мойкин Ю.В. Методики исследований в физиологии труда.- М.: Медицина, 1974.-311 с.

13. Доскин В.А., Лаврентьєва Н.А., Стронгина О.М., Шарай В.Б. Психологический тест "САН" применительно к исследованиям в области физиологии труда//Пигиена труда и проф. забол.- 1975.№5.- С. 28-32.

14. Закон України "Про загальну середню освіту" №́651-XIV від. 13.05.1999//Інф. зб. Мін. освіти і науки України.- 1999.- №15.- С. 6-31.

15. Галузинський В.М., Євнух М.Б. Педагогіка: теорія та історія: Навч. посібник.- К.: Вища шк., 1995.237 c.

16. Ахмерова С.Г. Здоровье педагогов: профессиональные факторы риска//Профилактика заболеваний и укрепление здоровья.-2001.- №4.- С.28-30. 
ヘатина А.A.

\section{OUЕНКА НАПРЯІКЕННОСТИ ТРУАОВОГО ПРОUЕССА УЧИТЕАЯ} ОБШЕОБРАЗОВАТЕАЬНОГО УЧЕБНОГО ЗАВЕАЕНИЯ

\section{Сумской государственный пеАагогический университет им. А.С.Макаренко}

Отсутствие нормативного статуса педагогической деятельности и оценки согласно гигиенической классификации труда по напряженности трудового процесса определяет актуальность проблемы. На основании анализа фактической рабочей нагрузки учителей по данным хронометража изучено распределение рабочего времени на выполнение профессиональных обязанностей. Установлено нарушение режима труда и отдыха учителя за счет увеличения недельной нагрузки и времени на выполнение вспомогательных операций. Согласно критериям Гигиенической классификации при оценке напряженности, труд учителя отнесен к III классу, 3 степени.

Ключевые слова: учитель, напряженность труда, хронометраж

\section{Latina G.O.}

\section{STRAIN ASSESSMENT OF TEACHER'S WORIK PROCESS IN GENERAL EDUCATION ESTABLISHMENTS}

Sumy State Pedagogical University named after A.S. Makarenko

The lack of a normative status for the pedagogical activity and its assessment by the hygienic classification of work, basing on the strain of the work process, determines the actuality of the problem. The distribution of the work time necessary for fulfillment of professional duties has been established, basing on the analysis of a teacher's actual working load according to time-study records. The violation of the teacher's work and rest schedule, due to the increase of the loading within a week and the time necessary for fulfillment of auxiliary operations, was stated. In accordance with criteria of hygienic classification by strain assessment the teacher's work is referred to Class III, degree 3.

Key words: teacher, work strain, time-study

\section{Надійшла: 28.08.2006}

Контактна особа: Латіна Ганна Олександрівна, аспірантка кафедри БОФК СумДПУ ім. А.С. Макаренка, 40002, м.Суми, вул. Роменська 93, 401(2), тел. (096)4245704, e-mail: vela2005@yandex.ru 